\title{
Irrigation Depth and Nitrogen Fertilization on Production and Quality of Cherry Tomatoes
}

\author{
Antonio P. dos Santos ${ }^{1}$, Adriana R. da Costa ${ }^{2}$, Patrícia C. Silva ${ }^{2}$, Pedro R. Giongo ${ }^{4}$, Marcio Mesquita ${ }^{3}$ \\ \& Anailda A. L. Drumond ${ }^{2}$ \\ ${ }^{1}$ College of Agronomy, Federal Institute Goiano, Ceres, GO, Brazil \\ ${ }^{2}$ State University of Goiás, Câmpus Santa Helena de Goiás, Brazil \\ ${ }^{3}$ College of Agronomy, Federal University of Goiás, Goiânia, Brazil \\ Correspondence: Antônio P. dos Santos, College of Agronomy, Federal Institute Goiano, Ceres, GO, Brazil. Tel: \\ 55-649-9335-4228. E-mail: tony.mury@hotmail.com
}

Received: February 25, 2019

Accepted: March 31, 2019 Online Published: May 15, 2019

doi:10.5539/jas.v11n6p547

URL: https://doi.org/10.5539/jas.v11n6p547

\begin{abstract}
Nitrogen fertilization and water supply are determinant factors for production and physical-chemical quality of cherry tomato. The objective of this study is to evaluate the productivity and quality of cherry tomatoes, cultivar Carolina, produced under different irrigation depth and nitrogen treatments. The experiment was conducted in a protected environment in randomized blocks and a $5 \times 3$ factorial design with three replications. The treatments were integrated by the combination of five irrigation depth consisting of 50,75, 100, 125 and $150 \%$ of replacement of the reference evapotranspiration (ETo), and three nitrogen treatments fertilization (common urea, urea with urease inhibitor and without the application of nitrogen). The productive and qualitative characteristics of tomato fruits were evaluated. Productivity was better responsive with the $125 \%$ ETo depth. The $100 \%$ ETo depth provided the highest titratable acidity. Nitrogen treatments did not promote differences in productivity and quality of tomatoes.
\end{abstract}

Keywords: evapotranspiration, irrigation management, nitrogen sources, water use efficiency

\section{Introduction}

Brazil is the eighth largest tomato producer in the world (FAO, 2015). This crop stands out because of its social and economic relevance. It may be cultivated in all regions of Brazil by the adoption of different techniques of cultivation and management during the whole year (Vilela, Melo, Boiteux, \& Clemente, 2012). The mini-tomato (Lycopersicum esculentum Mill) is mainly produced in the Center-West and Southeast regions of Brazil (Cunha, Sandri, Vieira, Cortez, \& Oliveira, 2014). These authors emphasized that farmers in these regions constantly need new crop, water and nutritional management options, which would make it possible to maximize profitability.

The cherry tomatoes have satisfactory market values according Maciel, Fernandes, Melo and Oliveira (2016). Thus, they have been more interested in farmers who spread their cultivation in a protected environment. However, for better yields and economic profitability, it is necessary that the factors inherent to nutrition, correct use of water, genetics and sanity be at adequate levels (Silva et al., 2013).

The water is one of the factors that present the greatest influence on tomato growth and development characteristics (Andrade, Noronha, Azevedo, Silva, \& Santos, 2017). Santana, Vieira and Barreto (2010) mentioned water deficiency as the factor that affects tomato production the most. Andrade, Noronha, Azevedo, Silva, and Santos (2017) indicated that fruit quality also responds negatively to both water excess and deficit, as well as inadequate fertilization. According to Soares et al. (2012), one of the main demands of producers is precisely to know the water requirement of tomatoes, and alternatives sources of $\mathrm{N}$.

Thus, irrigation should be adequately managed respecting the water requirement of the crop during its cycle, and the estimation of evapotranspiration is important in this determination (Xie \& Zhu, 2013). Recent studies have been carried out to evaluate the effects of drip irrigation depth on productivity and/or quality of tomato fruits, be it for industrial processing (Moreira et al., 2012; Silva et al., 2013) or for in natura consumption (Campagnol, Abrahão, Mello, Oviedo, \& Minami, 2014; Brito et al., 2015). However, studies correlating irrigation depth with the production and quality of cherry tomatoes are still scarce. 
Allied to an adequate water availability, the supply of nutrients is also fundamental, especially when it comes to nitrogen. This nutrient is required in a greater quantity by plants, and its application may be cause $\mathrm{N}$ losses in soil, especially when the source is urea, which has high hygroscopicity, but is also very susceptible to losses by volatilization (A. A. Silva, S. T. Silva, Vasconcelos, \& Lana, 2012).

Alternatives to reduce losses by volatilization are the use of slow or controlled sources of nitrogen. According to Caetano, Diniz, Benett, and Salomão (2015), studies using slow-release or polymer-coated urea are incipient and therefore need to be further investigated, especially in the cultivation of economically important vegetables such as tomatoes.

Among the determining factors in the production and quality of cherry tomatoes are nitrogen fertilization and an adequate water supply. Thus, the objective of this study is to evaluate the productivity and quality of cherry tomatoes, cultivar Carolina, produced under different irrigation depth and nitrogen fertilization treatments.

\section{Method}

This study was conducted at the State University of Goiás, Campus Santa Helena de Goiás, GO, in a protected environment. The area is located at $17^{\circ} 48^{\prime} 49^{\prime \prime} \mathrm{S}$ and $50^{\circ} 35^{\prime} 49^{\prime \prime} \mathrm{W}$, at 595 meters of altitude. According to Köppen, the climate of the region is Aw, with annual rainfalls in a bimodal distribution and two well-defined seasons: dry season (May-October) and rainy season (November-April). The average temperature is $25^{\circ} \mathrm{C}$, rainfall reaches approximately $1,500 \mathrm{~mm}$ annually, and the relative humidity is on average $53 \%$.

The experimental design comprised completely randomized blocks (CRB) in a $5 \times 3$ factorial design with 3 replicates, totaling 15 treatments and 45 plots. The first factor was that an irrigation depth, composed of 50, 75, 100, 125 and $150 \%$ of the reference evapotranspiration (ETo), and the second factor was three nitrogen treatments: 1-common urea (CU); 2-urea with urease inhibitor (UI); 3-without nitrogen (WN).

The local irrigation system was by drip. With pressure and working flow of 15 mca and $1.8 \mathrm{~L} \mathrm{~h}^{-1}$, respectively. Irrigation depth were obtained from evaporation data measured daily using a mini-evaporator built with PVC (polyvinyl chloride), $30 \mathrm{~cm}$ in diameter and $28.5 \mathrm{~cm}$ in height, making up a volume of $20 \mathrm{~L}$, leveled using a $0.7 \mathrm{~m}$ high wooden stand (Salomão, 2012). It should be noted that the mini-evaporator was calibrated from June 11 to 30 , 2016, due to the evaporation of the standard class A tank, as shown in Figure 1, and both were installed inside the protected environment.

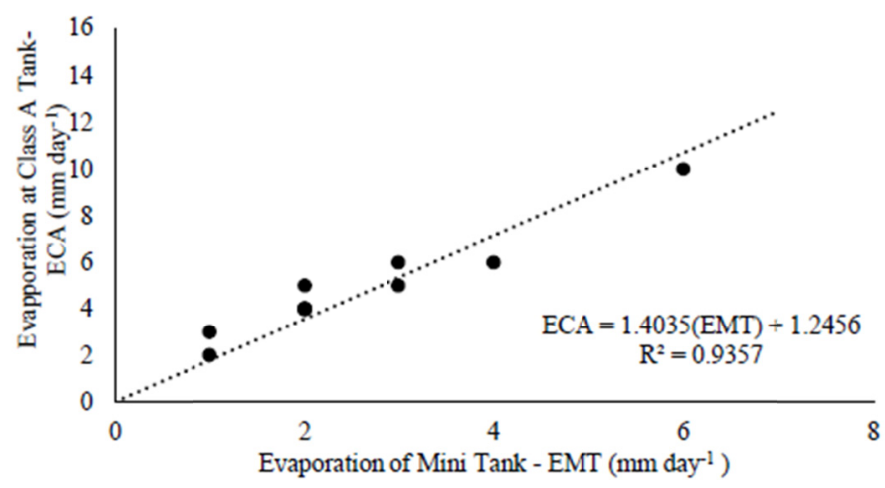

Figure 1. Calibration of the mini-evaporator with the standard class A tank, and its respective regression equation The crop evapotranspiration (ETc) was obtained by the Equation 1:

$$
\mathrm{ETC}=\mathrm{Kp} \times \mathrm{Kc} \times(\mathrm{Ev} \times \mathrm{f})
$$

where, $\mathrm{ETc}=$ crop evapotranspiration $\left(\mathrm{mm}\right.$ day $\left.^{-1}\right), \mathrm{Kp}=$ tank coefficient, dimensionless $(0.75$ for protected environment); $\mathrm{Kc}=$ crop coefficient (Doorenbos \& Kassam, 1994); Ev = evaporation of the mini-evaporator; $\mathrm{f}=$ evaporation correction factor for the standard class $\mathrm{A} \operatorname{tank}\left(\mathrm{mm} \mathrm{day}^{-1}\right)$.

The crop coefficient $(\mathrm{Kc})$ used varied according to the phenological phase of the crop (Table 1). For tomatoes, according to Doorenbos and Kassan (1994), the phases I to V correspond to the stages emergence of seedlings, post-emergence, flowering, reproductive and maturation, respectively. 
Table 1. Tomato crop coefficient $(\mathrm{Kc})$ for each stage of development, and number of days at each stage

\begin{tabular}{lll}
\hline Stage of Development & Number of Days per Phase & Kc values \\
\hline Phase I (Initial) & $10-15$ & 0.5 \\
Phase II (Development) & $20-30$ & 0.8 \\
Phase III (Intermediary) & $30-40$ & 1.2 \\
Phase IV (Last) & $30-40$ & 0.9 \\
Phase V (Harvest) & - & 0.6 \\
\hline
\end{tabular}

Source: Doorenbos and Kassan (1994).

Tomato Carolina was a cultivar selected for this study. It has a habit of indeterminate growth, a cycle of 100 to 115 days, tolerance to some diseases and high productivity of tasty fruits. Twenty-five days after sowing, cherry tomatoes were transplanted into pots with a volumetric capacity of $6 \mathrm{~L}$ of substrate. A soil representative of the Brazilian Cerrado region was used, it classified as Oxisol with a clayey texture. The pots were arranged $1.0 \mathrm{~m}$ apart between rows and $0.50 \mathrm{~m}$ apart between plants, as recommended. Soil acidity and nutrient supply were corrected based on chemical analysis (Table 2), as recommended by Ribeiro, Guimarães and Alvarez (1999).

Table 2. Chemical characterization of the soil used as substrate for cherry tomato cultivation in a protected environment

\begin{tabular}{lccccccccl}
\hline $\mathrm{Ca}$ & $\mathrm{Mg}$ & $\mathrm{Al}$ & $\mathrm{H}+\mathrm{Al}$ & $\mathrm{CEC}$ & $\mathrm{K}$ & $\mathrm{P}$ & $\mathrm{V}$ & $\mathrm{pH}$ & $\mathrm{OM}$ \\
\hline-1.7 & 0.7 & 0.0 & 4.2 & 6.72 & 45.0 & 7.7 & 37.5 & 5.0 & $\mathrm{~g} \mathrm{dm}^{-3}$ \\
\end{tabular}

Note. Ca: calcium; Mg: magnesium; $\mathrm{Al}$ : aluminum; $\mathrm{H}+\mathrm{Al}$ : hydrogen + aluminum; $\mathrm{CEC}$ : Cation exchange capacity; $\mathrm{K}$ : potassium; P: phosphorus; V: base saturation; $\mathrm{pH}$ : hydrogen potential in calcium chloride $\left(\mathrm{CaCl}_{2}\right)$; $\mathrm{OM}$ : soil organic matter.

Phosphate and potassium fertilization were performed for all treatments using the triple superfostate and potassium chloride sources, respectively. In contrast to nitrogen, different treatments (CU, UI and WN) were used according to the respective treatments. Both nitrogen and potassium were applied in cover using a split-plot design every 15 days throughout the crop cycle until the $8^{\text {th }}$ week, according to Table 3 . The phosphorus was applied at total dose at the time of transplanting tomato seedlings.

Table 3. Fertilization times and nutrient doses applied throughout the cultivation of cherry tomatoes in protected environment

\begin{tabular}{lllll}
\hline Application Time & Application Date & $\begin{array}{l}\text { Nitrogen Dose } \\
\left(\mathrm{kg} \mathrm{ha}^{-1} \text { of N }\right)\end{array}$ & $\begin{array}{l}\text { Potassium dose } \\
\left(\mathrm{Kg} \mathrm{ha}^{-1} \text { of } \mathrm{K}_{2} \mathrm{O}\right)\end{array}$ & $\begin{array}{l}\text { Phosphorus dose } \\
\left(\mathrm{Kg} \mathrm{ha}^{-1} \text { of }_{2} \mathrm{O}_{5}\right)\end{array}$ \\
\hline Transplantation & $05 / 23 / 16$ & 20 & 60 & 700 \\
$2^{\text {nd }}$ & $06 / 06 / 16$ & 20 & 90 & 300 \\
$3^{\text {rd }}$ & $06 / 21 / 16$ & 40 & 90 & - \\
$4^{\text {th }}$ & $07 / 04 / 16$ & 40 & 120 & - \\
$5^{\text {th }}$ & $07 / 19 / 16$ & 40 & 120 & - \\
\hline Total & - & 160 & 480 & 1000 \\
\hline
\end{tabular}

Note. The analyzed variables were productivity (Prod), fruit transverse diameter (TD), longitudinal fruit diameter (LD), number of fruits per plant $\left(\mathrm{NF} \mathrm{pl}^{-1}\right)$, fruit mass per plant $\left(\mathrm{FM} \mathrm{pl}^{-1}\right)$, total soluble solids (TSS), total titratable acidity (TTA), ratio and water use efficiency (WUE).

The TD and LDs of three representative fruits of each plant were measured using a digital caliper. For the determination of productivity (Prod) we counted $\mathrm{NF} \mathrm{pl}^{-1}$ and obtained $\mathrm{FM} \mathrm{pl}^{-1}$ on an analytical bullet. Afterwards, we extrapolated the results to yield per hectare, since the spacing adopted between plants was the same used in the field. 
The TSS content was determined using a portable sugar refractometer and the results were expressed in ${ }^{\circ} \mathrm{Brix}$, and the TTA was obtained by titration with $0.1 \mathrm{~N} \mathrm{NaOH}$. The ratio of TSS per TTA, called ratio (TSS/TTA), was calculated for the different samples. These analyses were performed after extraction of the broth from five tomatoes randomly selected from each plot, manually macerated and sieved. The relation between the average productivity of each plot and the irrigation depth applied throughout the crop cycle determined the WUE.

Data were submitted to analysis of variance associated with $\mathrm{F}$ test at a significance level of $5 \%$. For the evaluation of the irrigation depth, a regression analysis was used, and for the comparison between the nitrogen treatments, a Tukey test at $5 \%$ probability was performed. The statistical software SISVAR was used for statistical analyses (Ferreira, 2011).

\section{Results and Discussion}

Table 4 shows the F values and their significance for irrigation depth (IB), nitrogen treatments (NT) and their interactions according to productive characteristics: productivity (Prod.), fruit mass per plant (FM), number of fruits per plant (NF), and fruit quality parameters transverse diameter (TD), longitudinal diameter (LD), total soluble solids (TSS), total titratable acidity (TTA), and ratio and water use efficiency (WUE).

Table 4. F values of the analysis of variance of irrigation depth (IB), nitrogen treatments (NT) and their interactions $(\mathrm{IB} \times \mathrm{NT})$ according to the qualitative and productive characteristics of cherry tomatoes, and water use efficiency

\begin{tabular}{|c|c|c|c|c|c|c|c|c|c|c|}
\hline \multirow{2}{*}{ SV } & \multirow{2}{*}{ DF } & \multicolumn{5}{|c|}{ Qualitative Characteristics } & \multicolumn{3}{|c|}{ Quantitative Characteristics } & \multirow{2}{*}{ WUE $\left(\mathrm{kg} \mathrm{mm}^{-1}\right)$} \\
\hline & & TD & LD & TSS & TTA & Ratio & Prod. & $\mathrm{FM} \mathrm{pl}^{-1}$ & $\mathrm{NF}_{\mathrm{pl}} \mathrm{l}^{-1}$ & \\
\hline IB & 4 & $3.08 *$ & $5.87^{\mathrm{ns}}$ & $0.42^{\text {ns }}$ & $0.014 *$ & $12.82^{\mathrm{ns}}$ & $6,504.90 * *$ & $16.26 * *$ & $578.05 * *$ & $42.66 * *$ \\
\hline NT & 2 & $4.11 *$ & $9.53 *$ & $0.60^{\mathrm{ns}}$ & $0.006^{\mathrm{ns}}$ & $10.83^{\mathrm{ns}}$ & $20,754.29 * *$ & $51.89 * *$ & $689.17 * *$ & $94.51 * *$ \\
\hline $\mathrm{IB} \times \mathrm{NT}$ & 8 & $1.41^{\mathrm{ns}}$ & $4.27^{\mathrm{ns}}$ & $0.97^{\mathrm{ns}}$ & $0.005^{\mathrm{ns}}$ & $12.02^{\mathrm{ns}}$ & $1,080.53^{\mathrm{ns}}$ & $2.70^{\mathrm{ns}}$ & $2.35 *$ & $5.78 *$ \\
\hline Block & 2 & 1.79 & 5.1 & 0.34 & 0.007 & 3.99 & 363.03 & 0.91 & 7.41 & 3.76 \\
\hline Residue & 28 & 1.05 & 2.91 & 0.45 & 0.004 & 116.83 & 492.77 & 1.23 & 53.48 & 2.69 \\
\hline Total & 44 & - & - & - & - & - & - & - & - & - \\
\hline $\mathrm{CV}(\%)$ & - & 4.58 & 5.81 & 10.89 & 12.44 & 18.79 & 18.91 & 18.91 & 28.08 & 21.48 \\
\hline
\end{tabular}

Note. Productivity (Prod.), fruit mass per plant $\left(\mathrm{FM} \mathrm{pl}^{-1}\right)$, number of fruits per plant (NF), fruit transverse diameter (TD), and qualitative fruit parameters longitudinal fruit diameter (LD), total soluble solids (TSS), total titratable acidity (TTA), Ratio (TSS/ATT) and water use efficiency (WUE). CV: Coefficient of variation; SV: source of variation; DF: degree of freedom; ns: not significant, ** and *, significant at $1 \%$ and $5 \%$, respectively, by Tukey test.

Qualitative and quantitative characteristics had a significant effect on irrigation depth, except for the LD, TSS and Ratio variables. TD and TTA were significant at $5 \%$ probability. On the other hand, Prod, $\mathrm{FM} \mathrm{pl}^{-1}, \mathrm{NF} \mathrm{pl}^{-1}$ and WUE were significant at $1 \%$ level. For nitrogen treatments, Prod., $\mathrm{FM} \mathrm{pl}^{-1}$ and $\mathrm{NF} \mathrm{pl}^{-1}$ were significant at $1 \%$ probability, and TD and LD were significant at 5\% probability. In the interaction of factors between IB and NS, only the characteristics NF and WUE were significant at $5 \%$ probability.

The $\mathrm{NF} \mathrm{pl}^{-1}$, in function of the irrigation depth in the treatment with $\mathrm{CU}$, presented a higher value with the depth of $126.24 \%$ of ETo, in which it reached the average of 37.41 of fruits per plant (Figure 2A). Regarding the UI treatment, the mean number of fruits per plant was 32.62 and the depth that allowed this average was $112 \%$ of the ETo. In the WN treatment, the fruit average was below the other treatments, reaching only 24.7 fruits per plant, requiring an irrigation depth of $118.38 \%$ of ETo. This low number of fruits found in the treatment without $\mathrm{N}$ (Table 5) reinforces the idea of the centrality of this nutrient for the increase in tomato fruit production. 
Table 5. Test of means of the parameters Transversal diameter (TD), longitudinal diameter (LD), total soluble solids (TSS), total titratable acidity (TTA), ratio (TSS/ATT), productivity (Prod.), fruit mass per plant $\left(\mathrm{FM} \mathrm{pl}^{-1}\right)$, number of fruits per plant $\left(\mathrm{NF} \mathrm{pl}^{-1}\right)$ and water use efficiency (WUE) of cherry tomatoes cultivated in a protected environment using nitrogen treatments (NT) and irrigated with different irrigation depth

\begin{tabular}{llllllllll}
\hline NT & TD $(\mathrm{mm})$ & LD $(\mathrm{mm})$ & TSS $\left({ }^{\circ}\right.$ Brix $)$ & TTA $(\%)$ & Ratio & ${\text { Prod. }\left(\mathrm{tha}^{-1}\right)}^{\mathrm{NF} \mathrm{pl}^{-1}}$ & $\mathrm{FM} \mathrm{pl}^{-1}(\mathrm{~g})$ & $\left.\mathrm{WUE}_{(\mathrm{kg} \mathrm{mm}}{ }^{-1}\right)$ \\
\hline $\mathrm{WN}$ & $21.98 \mathrm{~b}$ & $28.51 \mathrm{~b}$ & $5.96 \mathrm{a}$ & $0.50 \mathrm{a}$ & $11.19 \mathrm{a}$ & $2.35 \mathrm{~b}$ & $18.37 \mathrm{~b}$ & $0.12 \mathrm{~b}$ & $4.75 \mathrm{~b}$ \\
$\mathrm{CU}$ & $22.21 \mathrm{ab}$ & $29.44 \mathrm{ab}$ & $6.29 \mathrm{a}$ & $0.52 \mathrm{a}$ & $12.21 \mathrm{a}$ & $4.36 \mathrm{a}$ & $28.57 \mathrm{a}$ & $0.22 \mathrm{a}$ & $8.84 \mathrm{a}$ \\
$\mathrm{UI}$ & $22.98 \mathrm{a}$ & $30.10 \mathrm{a}$ & $6.31 \mathrm{a}$ & $0.54 \mathrm{a}$ & $12.81 \mathrm{a}$ & $4.42 \mathrm{a}$ & $31.20 \mathrm{a}$ & $0.22 \mathrm{a}$ & $9.31 \mathrm{a}$ \\
\hdashline $\mathrm{LSD}$ & 0.93 & 1.54 & 0.61 & 0.017 & 1.85 & 0.63 & 6.61 & 0.03 & 1.48 \\
\hline
\end{tabular}

Note. CU: common urea, UI: urea with urease inhibitor, WN: without nitrogen; LSD: least significant difference. Means followed by the same lowercase letter in colun do not differ by Tukey test at $5 \%$ probability.
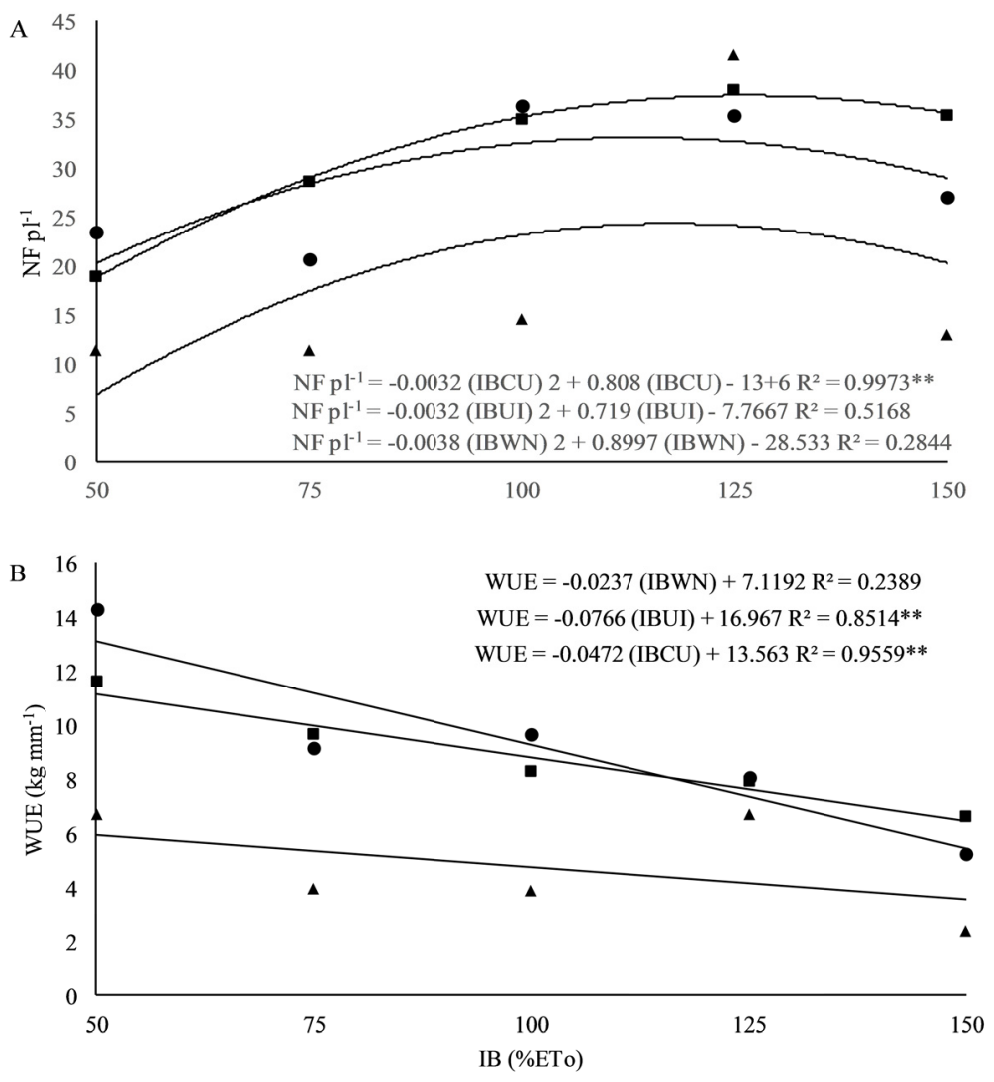

Figure 2. Avarege of numbers of fruits per plant $\left(\mathrm{NF} \mathrm{pl}^{-1}\right)$ of cherry tomato (A) cultivated in a protected environment and water use efficiency (WUE) (B) in function of nitrogen treatments for each irrigation blade (IB) determined in function of the reference evapotranspiration (\% ETo). UI: urea with urease inhibitor. CU: common urea. WN: without $\mathrm{N}$

Santana, Vieira, and Barreto (2010) observed that smaller or larger irrigation depth in relation to the $100 \%$ replacement resulted in losses of productivity and number of fruits per plant, indicating as an optimal physical irrigation depth $460.17 \mathrm{~mm}$, in which there were 30.56 fruits per salad tomato plant. The total depth applied to the cycle of the cherry tomato studied were $259.5,389.25,519,648.75$ and $778.5 \mathrm{~mm}$, corresponding to $50 \%, 75 \%$, $100 \%, 125 \%$ and $150 \%$ of ETo, respectively. In this study, this same irrigation depth as cited by Santana, Vieira and Barreto (2010), of $460.17 \mathrm{~mm}$, resulted in 23.46 fruits per plant.

For TD, the data ranged from 25 to $33 \mathrm{~mm}$ (Table 5). For LD, cherry tomato fruits varied between 25.91 and 34.28 $\mathrm{mm}$. Preczenhak et al. (2014) performed a characterization of mini-tomato genotypes, and the diameter varied between 20 and $40 \mathrm{~mm}$. Tomatoes may be classified as small when they have between 20 and 25 mm, medium 
between 25 and $30 \mathrm{~mm}$, large between 30 and $35 \mathrm{~mm}$ and giant when greater than $35 \mathrm{~mm}$ (Fernandes, Corá and Braz, 2007). In this study, therefore, the cherry tomato class would be between medium and large.

By observing Table 5, it was found that, for the TD and LD of the fruits, only the treatment with urease inhibitor differed from that without nitrogen. The factor irrigation depth influenced the TD of fruits. For higher values, an intermediate depth was required, in which it reached $22.15 \mathrm{~mm}$ in diameter using a $78.5 \%$ ETo depth regardless of the nitrogen treatment used (Figure 3A). Silva et al. (2013) analyzed the cultivation of the Caline IPA 6 tomato in a protected environment under different evapotranspiration replacement rates and observed that the transversal diameter maintained its averages between 28.5 and $45.5 \mathrm{~mm}$ for depth between 33 and 166\% of ETo. In this study, the behavior was quadratic, with the vertex facing downwards, indicating that intermediate irrigation depth presented smaller fruits, were verified with application of these irrigation depth.

For the optimum irrigation depth, $127.06 \%$ of ETo, regardless of the nitrogen treatment, there was a mean fruit mass per plant of $212.75 \mathrm{~g}$, as observed in the Figure 3C. On the other hand, Silva et al. (2013) found that the irrigation depth that provided the best yield of fruit mass per plant was the $128 \%$ of the ETo for the cultivar Caline IPA 6. A similar result was found in this study. Regarding productivity, the CU treatment obtained the best fit between the estimated and the observed data.

Feltrin, Pott, Furlani and Carvalho (2005) reported that the TTA reaches the maximum value when still with a yellow coloration, and this value reduces as the tomato fruit matures. Ferreira et al. (2010) stated that the tomato harvested in the first flowering tend to present a higher TTA, an observation also made by Vieira, Cardoso, Dourado, Caliari and Soares Júnior (2014) and observed in this study. The mean value of $0.374 \%$ TTA of cherry tomatoes in a conventional and organic cultivation was within the range found in this study, whose values varied between 0.30 and $0.68 \%$, but did not show differences in function of nitrogen fertilization. For the TTA of $0.55 \%$, a depth of $100 \%$ of ETo was applied regardless of the nitrogen treatment used (Figure 3B).

Regarding the physical-chemical quality of cherry tomatoes, TSSs reflect the sweetness of the product, indicate maturity/ripeness level and may be expressed in ${ }^{\circ}$ Brix (Pineli, 2009). Ramos et al. (2013) stated that fertilization, temperature, irrigation and the genetic influenced the character of the cultivar. According to Schwarz et al. (2013), a fruit with values higher than $3^{\circ}$ Brix is recommended for marketing in natura. In this study, the content of TSS varied from 4.0 to $8.0^{\circ} \mathrm{Brix}$, with the lowest values observed in the treatment without addition of $\mathrm{N}$ (Table 5).

According to Moura et al. (2017), studies reporting the water use efficiency for cherry tomatoes are scarce. The WUE showed an inverse behavior of productivity; Santana, Vieira, and Barreto (2010) observed the same behavior upon analyzing the response of irrigated tomatoes to levels of water replacement in the soil. Based on the equations of each treatment of $\mathrm{N}$ (Figure 2B), it is observed that the reduction rate of WUE was 77, 47 and $23 \mathrm{~g} \mathrm{~mm}^{-1}$, for UI, $\mathrm{CU}$ and $\mathrm{WN}$, respectively. Efficiency of water use is directly related to productivity. The higher the productivity, as even water consumption, the greater the effectiveness of water use.

Abrahão et al. (2014) found different WUEs for cherry tomato cultivars: 'Swett Milion' had $29.1 \mathrm{~kg} \mathrm{~m}^{-3}$ and 'Sweet Grape' had $22.3 \mathrm{~kg} \mathrm{~m}^{-3}$. According to Moura et al. (2017), the differences in water use efficiency values may be attributed to the cultivars studied, local climatic conditions and planting spacing, and in this study, it was observed that nitrogen fertilization also exerts a great influence. 

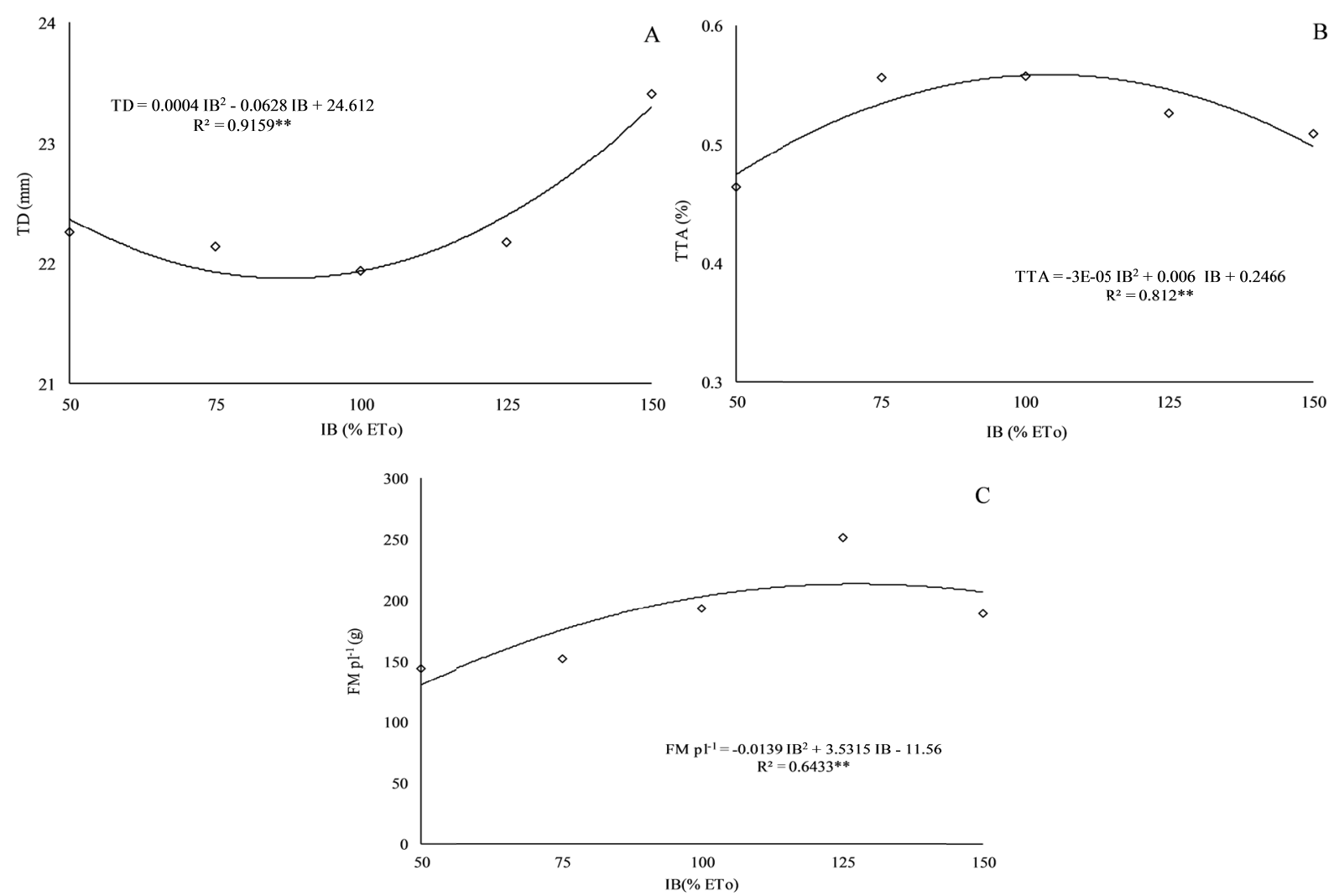

Figure 3. (A) Transverse diameter (TD) (B) total titratable acidity (TTA) and (C) fruit mass per plant (FM pl $\left.{ }^{-1}\right)$ of cherry tomatoes cultivated in a protected environment according to nitrogen treatments and irrigation blade (IB), determined in function of reference evapotranspiration (ETo)

\section{Conclusions}

The irrigation depth that resulted in the highest productivity was the $117.67 \%$ of ETo. Only TTA among the physical-chemical characteristics of tomatoes showed an interference of irrigation depth. The $100 \%$ ETo depth provided slightly more acidic fruits. The irrigation depth equivalent to $100 \%$ of the ETo resulted in a superior quality in relation to the parameters that please the consumer market.

For the common urea, the irrigation depth of $126.24 \%$ ETo provided the highest number of fruits per plant. And for the urea with urease inhibitor, the depth that allowed the greatest response to this variable was the $112 \%$ of ETo. In the without nitrogen treatment, the irrigation depth that promoted the best response for all the analyzed characteristics was the equivalent to $118.38 \%$ of the ETo. The first two are more efficient in water use because they provide the greatest efficiency in the use of the water applied to the soil.

\section{References}

Abrahão, C., Villas Bôas, R. L., \& Bull, L. T. (2014). Relação K: Ca: Mg na solução nutritiva para a produção de minitomate cultivado em substrato. Irriga, 19(2), 214-224. https://doi.org/10.15809/irriga.2014v19n2p214

Andrade, A. R. S., Noronha, S. P., Azevedo, P. R., Silva, P. R. L. A., \& Santos, R. C. (2017). Fertirrigação no cultivo de quatro cultivares de tomate (Lycopersicum sculentum) irrigado por gotejamento. Applied Research \& Agrotechnology, 10(2), 07-21. https://doi.org/10.5935/PAeT.V10.N2.01

Brito, M. E. B., Soares, L. A. A., Lima, G. S., Sá, F. V. S., Araújo, T. T., \& Silva, E. C. B. (2015). Crescimento e formação de fitomassa do tomateiro sob estresse hídrico nas fases fenológicas. Irriga, 10(1), 139-153. https://doi.org/10.15809/irriga.2015v20n1p139

Caetano, A. O., Diniz, R. L. C., Benett, C. G. S., \& Salomão, L. C. (2015). Efeito de fontes e doses de nitrogênio na cultura do rabanete. Revista Agricultura Neotropical, 2(4), 55-59. https://doi.org/10.32404/rean.v2i4.286 
Campagnol, R., Abrahão, C., Mello, S. C., Oviedo, V. R. S. C., \& Minami, K. (2014). Impactos do nível de irrigação e da cobertura do solo na cultura do tomateiro. Irriga, 19(3), 345-357. https://doi.org/10.15809/ irriga.2014v19n3p345

Cunha, A. H. N., Sandri, D., Vieira, J. A., Cortez, T. B., \& Oliveira, T. H. (2014). Sweet grape mini tomato grown in culture substrates and effluent with nutrient complementation. Engenharia Agricola, 34(4), 707-715. https://doi.org/10.1590/S0100-69162014000400010

Doorenbos, L., \& Kassan, A. H. (1994). Efeito da água no rendimento das culturas. In H. R. Gheyi, A. A. Sousa, F. A. V. Damasceno, \& J. F. Medeiros (Trans.), Estudos FAO: Irrigação e Drenagem 33 (p. 306). Campinas Grande, UFPR.

FAO (Food and Agriculture Organization of the United Nations). (2015) FAOSTAT. Retrieved from http://faostat.fao.org/site/567/default.aspx\#ancor

Feltrin, D. M., Pott, C. A., Furlani, P. R., \& Carvalho, C. R. L. (2005). Produtividade e qualidade de frutos de cultivares de tomateiro fertirrigado com cloreto e sulfato de potássio. Revista Ciências Agroveterinárias, 4(1), $17-24$.

Fernandes, C., Corá, J. E., \& Braz, L. T. (2007). Classificação de tomate-cereja em função do tamanho e peso dos frutos. Horticultura Brasileira, 25(2), 275-278. https://doi.org/10.1590/S0102-05362007000200029

Ferreira, D. F. (2011). Sisvar: A computer statistical analysis system. Ciência e Agrotecnologia, 35(6), 1039-1042. https://doi.org/10.1590/S1413-70542011000600001

Ferreira, S. M. R., Freitas, R. J. S., Karkle, E. N. L., Quadros, D. A., Tullio, L. T., \& Lima, J. J.(2010). Qualidade do tomate de mesa cultivado nos sistemas convencional e orgânico. Ciência e Tecnologia de Alimentos, 30(1), 224-230. https://doi.org/10.1590/S0101-20612010000100033

Maciel, G. M., Fernandes, M. A. R., Melo, O. D., \& Oliveira, C. S. (2016). Potencial agronômico de híbridos de minitomate com hábito de crescimento determinado e indeterminado. Horticultura Brasileira, 34(1), 144-148. https://doi.org/10.1590/S0102-053620160000100022

Moreira, J. A. A., Cardoso, A. F., Costa, L. L., Rodrigues, M. S., Peixoto, N., \& Braz, L. T. (2012). Manejo da irrigação para otimização da produtividade e qualidade de frutos de tomate em sistema plantio direto. Irriga, 14(4), 408-417. https://doi.org/10.15809/irriga.2012v17n4p408

Moura, M. S. B., Souza, L. S. B., Oliveira, L. D. S., Silva, T. G. F., \& Yuri, J. E. (2017). Biometria e eficiência do uso da água em tomate cereja no semiárido. Revista Brasileira de Agrometeorologia, 25(1), 163-171.

Pineli, L. L. O. (2009). Qualidade e potencial antioxidante in vitro de morangos in natura e submetidos a processamentos (p. 222, Tese de doutorado, Universidade de Brasília, Brasília).

Preczenhak, A. P., Resende, J. T. V., Chagas, R. R., Silva, P. R., Schwarz, K., \& Morales, R. G. F. (2014). Caracterização agronômica de genótipos de minitomate. Horticultura Brasileira, 32(3), 348-356. https://doi.org/10.1590/S0102-053620140003000018

Ramos, A. R. P., Amaro, A. C. E., Macedo, A. C., Sugawara, G. S. A., Evangelista, R. M., Rodrigues, J. D., \& Ono, E. O. (2013). Qualidade de frutos de tomate 'Giuliana' tratados com produtos de efeitos fisiológicos. Semina: Ciências Agrárias, 4(6), 3543-3552.

Ribeiro, A. C., Guimarães, P. T. G., \& Alvarez, V. V. H. (1999). Recomendações para o uso de corretivos e fertilizantes em Minas Gerais (5 Aproximação, p. 359). Viçosa: CFSEMG.

Salomão, L. C. (2012). Calibração de tanques evaporímetros de baixo custo sob diferentes diâmetros em ambiente protegido (Tese (Doutorado), Universidade Estadual Paulista "Júlio de Mesquita Filho", Botucatu, São Paulo).

Santana, M. J., Vieira, T. A., \& Barreto, A. C. (2010). Resposta do tomateiro irrigado a níveis de reposição de água no solo. Irriga, 15(4), 443-454. https://doi.org/10.15809/irriga.2010v15n4p443

Schwarz, K., Resende, J. T. V., Preczenhak, A. P., Paula, J. T., Faria, M. V., \& Dias, D. M. (2013). Desempenho agronômico e qualidade físico-química de híbridos de tomateiro em cultivo rasteiro. Horticultura Brasileira, 31(3), 410-418. https://doi.org/10.1590/S0102-05362013000300011

Silva, A. A., Silva, T. S., Vasconcelos, A. C. P., \& Lana, R. M. Q. (2012). Aplicação de diferentes fontes de ureia de liberação gradual na cultura do milho. Bioscience Journal, 28(S. 1), 104-111. 
Silva, J. M., Ferreira, R. S., Melo, A. S., Suassuna, J. F., Dutra, A. F., \& Gomes, J. P. (2013). Cultivo do tomateiro em ambiente protegido sob diferentes taxas de reposição da evapotranspiração. Revista Brasileira de Engenharia Agrícola e Ambiental, 17(1), 40-46. https://doi.org/10.1590/S1415-43662013000100006

Soares, L. A. A., Lima, G. S., Brito, M. E. B., Sá, F. V. S., Silva, E. C. B., \& Araújo, T. T. (2012). Cultivo do tomateiro na fase vegetativa sobre diferentes lâminas de irrigação em ambiente protegido. Agropecuária Científica no Semiárido, 8(2), 38-45.

Vieira, D. A. P., Cardoso, K. C. R., Dourado, K. K., Caliari, M., \& Soares Júnior, M. S. (2014). Qualidade física e química de mini-tomates Sweet Grape produzido em cultivo orgânico e convencional. Revista Verde Agroecologia e Desenvolvimento Sustentável, 9(3), 100-108.

Vilela, N. J., Melo, P. C. T., Boiteux, L. S., \& Clemente, F. M. V. T. (2012). Perfil socioeconômico da cadeia agroindustrial no Brasil. In F. M. V. T. Clemente, \& L. S. Boiteux (Org.), Produção de tomate para processamento industrial (2nd ed., pp. 17-30). Brasília: Embrapa.

Xie, H., \& Zhu, X. (2013). Reference evapotranspiration trends and their sensitivity to climatic change on the Tibetan Plateau (1970-2009). Hydrological Processes, 27(25), 3685-3693. https://doi.org/10.1002/hyp.9487

\section{Copyrights}

Copyright for this article is retained by the author(s), with first publication rights granted to the journal.

This is an open-access article distributed under the terms and conditions of the Creative Commons Attribution license (http://creativecommons.org/licenses/by/4.0/). 